\title{
PERSEPSI MASYARAKAT TENTANG COVID 19
}

Try Ayu Amanda Pasaribu

\author{
tryayuamanda08@gmail.com
}

\section{LATAR BELAKANG}

Persepsi adalah proses mental untuk mengidentifikasi, mengevaluasi, dan menanggapi situasi apapun di sekitar. Pengetahuan, pengalaman, dan orientasi sosial budaya akan menentukan Citra dan perspektif masalah. Perbedaan pengalaman, analisis dan pengetahuan, merupakan kerangka menggambarkan hasil persepsi antar individu yang berbeda-beda. Persepsi masyarakat merupakan suatu proses ulang yang dialami oleh manusia pada suatu lingkungan tertentu dan memberikan pengetahuan atau gagasan yang positif dan negatif kepada masyarakat sekitar.

Wabah Corona (Covid 19) telah melanda negara-negara dunia, pemerintah sebagai pengatur dan memberikan perlindungan kepada rakyatnya mengeluarkan regulasi kebijakan yang cepat dan efisien guna penyelamatan kan negara dari berbagai resensi sesuai dengan peraturan perundang-undangan, pemerintah pusat mengeluarkan peraturan dan pendelegasian kewenangan kepada pemerintah daerah telah diatur dalam UUD 1945. Daerah adalah kesatuan masyarakat hukum yang mempunyai batas wilayah tertentu berwenang serta berkewajiban mengatur membuat peraturan-peraturan dan mengurus administrasi pemerintah daerah dalam ikatan negara kesatuan Republik Indonesia sesuai dengan peraturan perundang-undangan yang berlaku.

Berdasarkan bukti ilmiah, Covid 19 dapat menular dari manusia ke manusia melalui percikan batuk/bersin, orang yang paling beresiko tertular Penyakit ini adalah orang yang kontak erat dengan pasien Covid 19 termasuk yang merawat pasien Covid 19. Rekomendasi standar untuk mencegah penyebaran infeksi adalah melalui cuci tangan secara teratur menggunakan sabun dan air bersih, menerapkan etika batuk dan bersin, menghindari kontak secara langsung dengan ternak dan hewan liar serta menghindari kontak dekat dengan siapapun yang menunjukkan gejala penyakit pernapasan seperti batuk dan bersin. Selain itu menerapkan pencegahan dan pengendalian infeksi (PPI) saat berada di fasilitas kesehatan terutama masyarakat. (WHO,2020). 
Menurut penelitian Saryani (2020) dalam penelitian implementasi gaya hidup kerohanian mahasiswa IAKN Toraja dalam menyikapi pencegahan Covid 19 menyatakan bahwa masyarakat sangat risau dengan adanya Covid 19 ini ini apalagi dikalangan mahasiswa itu sebabnya penting menerapkan pencegahan Covid 19.

Berdasarkan hasil analisis pelaksanaan pencegahan Covid 19 di Kelurahan Talikuran Utara Kecamatan Kawangkoan Utara adalah sebagai berikut, Dalam memiliki persepsi bahwa virus Corona sangat mengkhawatirkan dan meresahkan warga. Masyarakat masih kurang paham apa arti dari Covid 19 dan tindakan apa saja yang sebaiknya masyarakat tetap kan di sini dibutuhkan kerjasama antara pemerintah dan masyarakat dalam menangani Covid 19. Adapun persepsi dari masyarakat sendiri bahwa pembagian APD masih sangat kurang terhadap tenaga medis.

\section{METODE}

Metode yang digunakan pada kajian ini adalah dengan menganalisis dari berbagai sumber bacaan. Referensi yang saya ambil dari jurnal online dengan penelitian yang berbedabeda dengan pengerjaannya dengan cara membandingkan artikel satu dengan artikel yang lain. Metode yang digunakan pengkajian ini dengan mengumpulkan informasi dari berbagai referensi termasuk didalamnya hasil-hasil penelitian.

\section{HASIL}

Hasil dari pengkajian ini Corona virus atau Covid 19 merupakan pandangan yang telah mengakibatkan tingginya angka mortalitas di berbagai belahan dunia. Pengetahuan mengenai pandemi Covid 19 yang baik dan perilaku hidup bersih dan sehat sebagai upaya mencegah penularan Covid 19 penting untuk diterapkan.

Pandemi Covid 19 yang disebabkan oleh virus SARS-CoV-2 menjadi peristiwa yang mengancam kesehatan masyarakat secara umum dan telah menarik perhatian dunia. Pada tanggal 30 Januari 2020, WHO (World Health Organization) telah menetapkan Covid 19 sebagai keadaan darurat kesehatan masyarakat yang menjadi perhatian dunia internasional.

Peningkatan kasus Covid 19 yang terjadi di masyarakat didukung oleh proses penyebaran virus yang cepat, baik dari hewan ke manusia ataupun antara manusia. Penularan virus SARS-COV-2 dari hewan ke manusia utamanya disebabkan oleh konsumsi hewan yang terinfeksi virus tersebut sebagai sumber makanan manusia, utamanya hewan kelelawar. Proses 
Penularan Covid 19 kepada manusia harus diperantarai oleh reservoir kunci yaitu alphacoronavirus dan betacoronavirus yang memiliki kemampuan menginfeksi manusia. Kontak yang erat dengan pasien terinfeksi Covid 19 akan mempermudah proses penularan Covid 19 antara manusia. Proses penularan Covid 19 disebabkan oleh pengeluaran rufflet yang mengandung virus SARS-COV-2 ke udara oleh pasien terinfeksi pada saat batuk atau pun bersin. Droplet di udara selanjutnya dapat terhirup oleh manusia lain di dekatnya yang tidak terinfeksi Covid 19 melalui hidung atau pun mulut. Droplet selanjutnya masuk menembus paru-paru dan proses infeksi pada manusia yang sehat. Secara klinis, representasi adanya infeksi virus SARS-COV-2 pada manusia dimulai dari adanya asimtomatik hingga pneumonia sangat berat, dengan sindrom akut pada gangguan pernapasan, syok septik dan kegagalan multi organ, yang berujung pada kematian. Hal ini akan meningkatkan ancaman dalam masa pandemi Covid 19 sehingga jumlah kasus Covid 19 di masyarakat dapat terus meningkat. Guna melawan adanya peningkatan kasus Covid 19, maka berbagai tindakan preventif mutlak harus dilaksanakan, baik oleh pemerintah ataupun masyarakat. Upaya preventif sejauh ini merupakan praktik terbaik untuk mengurangi dampak pandemi Covid 19, mengingat belum adanya pengobatan yang dinilai efektif dalam melawan virus SARS-COV-2. Saat ini, tidak adanya vaksin untuk SARS-COV-2 yang tersedia dan telah memenuhi berbagai fase uji klinis, sehingga upaya preventif terbaik yang dilakukan adalah dengan menghindari paparan virus dengan didasarkan pada PHBS (Perilaku Hidup Bersih dan Sehat). Untuk mencapai tujuan ini, langkah-langkah utama yang hendak dilaksanakan masyarakat seperti penggunaan masker, menutup mulut dan hidung saat bersin atau batuk, mencuci tangan secara teratur dengan sabun atau desinfektan dengan pembersih tangan yang mengandung setidaknya $60 \%$ alkohol, menghindari kontak dengan orang yang terinfeksi, menjaga jarak dari orang-orang, menahan diri dari menyentuh mata, hidung, dan mulut dengan tangan yang tidak dicuci. Pengetahuan dan tindakan yang nyata dari pemerintah dan masyarakat terkait PHBS akan senantiasa mampu menurunkan jumlah kasus Covid 19, sehingga masa pandemi Covid 19 dapat berakhir dengan cepat.

\section{PEMBAHASAN}

Persepsi masyarakat merupakan suatu proses ulang yang dialami oleh manusia pada suatu lingkungan tertentu dan memberikan pengetahuan atau gagasan yang positif dan negatif kepada masyarakat sekitar. Kenneth K.Sereno dan Edward M.Bodaken dalam Mulyana (2017) memecah persepsi menjadi 3 (tiga) kegiatan yaitu : Seleksi, Organisasi, dan Interpretasi. Seleksi terdiri dari sensasi dan perhatian, sedangkan organisasi dekat dengan interpretasi. Ini 
tegas untuk membedakan semua itu, karena kita tidak tahu kapan satu fase berakhir dan fase berikutnya dimulai dan cenderung berlangsung secara bersamaan. Persepsi adalah proses individu untuk memilih, mengatur, dan menafsirkan informasi untuk membuat atau menghasilkan deskripsi yang bermakna.

Kehadiran virus jenis baru yang belum ditemukan obatnya ini membuat masyarakat cemas, ketakutan, dan bahkan depresi. Memberikan dampak negatif Covid 19, media juga mendorong masyarakat untuk menerapkan budaya hidup bersih dan sehat, meningkatkan kesadaran, dan meningkatkan pemahaman tentang bahaya atau efek penyakit. Terkait budaya hidup bersih dan sehat, yang dimaksudkan agar masyarakat semakin peduli dan sadar akan pentingnya mencuci tangan dengan benar, pentingnya mengonsumsi buah dan sayur, serta konsumsi jenis makanan yang seimbang dan berolahraga. Terkait peningkatan kesadaran masyarakat dan pemahaman masyarakat, sikap antisipasi dari masyarakat didorong dengan mencari sumber informasi untuk mencegah dan menghindari penyakit

Covid 19 pertama kali merebak di Kota Wuhan, Tiongkok pada akhir tahun 2019. Meskipun pemerintah baru mengumkan kasus pertama di Indonesia pada awal Maret 2020, banyak pihak percaya bahwa Covid 19 sudah jauh lebih dulu menjangkiti masyarakat Indonesia. Segera setelah pengumuman resmi tersebut, pemerintah menghimbau agar masyarakat melakukan social distancing (sd) yang diartikan sebagai pembatasan diri untuk keluar rumah, menghindari kerumunan, dan menjaga jarak fisik. Sebagian masyarakat muslim merespon himbauan tersebut dengan mengatakan bahwa himbauan tersebut selaras dengan tuntunan Rasulullah Muhammad SAW dalam menangani wabah penyakit menular. Kelompok ini kemudian banyak mengedukasi masyarakat akan pentingnya $s d$ baik dari segi medis maupun dari segi mengikuti tuntunan Rasulullah dalam menangani wabah. Kelompok lain mengedukasi masyarakat lewat sejarah penanganan wabah wabah di masa lalu. Penerapan sd di Indonesia tidak disertai dengan ancaman hukuman atau penertiban menyeluruh oleh aparat yang berwenang. Karena itu, implementasinya sangat bergantung pada kesadaran masyarakat sendiri. Sementara itu, ketika di satu sisi mayoritas masyarakat sepakat bahwa sd sangat penting diterapkan, namun disisi lain mereka tidak sepaham dengan perlu tidaknya tempat ibadah ikut ditutup. Masuknya bulan Ramadhan menambah keinginan sebagian masyarakat untuk beribadah di masjid dan mushola. Disaat yang sama, kebutuhan masyarakat untuk mencari pemasukan guna menyambung hidup memaksa sebagian masyarakat untuk tetap melakukan keseharian seperti biasa. Selain itu terdapat pula kelompok yang menganggap remeh penyebaran Covid 19 serta tidak mengindahkan protokol kesehatan yang telah 
ditetapkan Badan Kesehatan Dunia (WHO) Dan menganggap Covid 19 sebagai sebuah konspirasi dan rekayasa.

Covid 19 adalah penyakit yang disebabkan oleh Corona virus yang menjadikan pandemik di seluruh negara terutama Indonesia. Penyakit Covid 19 dapat dicegah diantaranya yaitu dengan pengetahuan dan kepatuhan masyarakat dalam penggunaan masker sebagai upaya pencegahan penyakit Covid 19. Kepatuhan adalah istilah yang digunakan untuk menggambarkan perilaku masyarakat dalam menggunakan masker. Kepatuhan adalah perilaku positif yang diperlihatkan masyarakat saat masyarakat menggunakan masker. Faktor-faktor yang mempengaruhi kepatuhan tergantung pada banyak faktor, termasuk pengetahuan, motivasi, persepsi, dan keyakinan terhadap upaya pengontrolan dan pencegahan penyakit, variabel lingkungan, kualitas intruksi kesehatan, dan kemampuan mengakses sumber yang ada. Sedangkan ketidakpatuhan adalah kondisi ketika individu atau kelompok berkeinginan untuk patuh, tetapi Ada sejumlah faktor yang menghambat kepatuhan terhadap saran tentang kesehatan yang diberikan oleh tenaga kesehatan.

Pengetahuan tentang penyakit Covid 19 merupakan hal yang sangat penting agar tidak menimbulkan peningkatan jumlah kasus penyakit Covid 19. Pengetahuan pasien Covid 19 dapat diartikan sebagai hasil tahu dari pasien mengenai penyakitnya, memahami penyakitnya, cara pencegahan, pengobatan dan komplikasinya. Pengetahuan memegang peranan penting dalam penentuan perilaku yang utuh karena pengetahuan akan membentuk kepercayaan yang selanjutnya dalam mempersepsikan kenyataan, memberikan dasar bagi pengambil keputusan dan menentukan perilaku terhadap objek tertentu sehingga akan mempengaruhi seseorang dalam berperilaku.

Covid 19 adalah penyakit menular yang disebabkan oleh jenis Corona virus yang baru ditemukan. Virus baru dan penyakit yang disebabkannya ini tidak kenal sebelum mulainya wabah di Wuhan, Tiongkok. Sedangkan yang dimaksud corona virus adalah suatu kelompok virus yang dapat menyebabkan penyakit pada hewan atau manusia. Beberapa jenis coronavirus diketahui menyebabkan infeksi saluran napas pada manusia mulai dari batuk pilek hingga yang lebih serius. Orang dapat tertular Covid 19 dari orang lain yang terinfeksi virus ini. Covid 19 dapat menyebar terutama dari orang ke orang melalui percikkan percikkan dari hidung atau mulut yang keluar saat orang yang terinfeksi Covid 19 batuk,bersin atau berbicara. Percikanpercikan ini relatif berat, perjalanannya tidak jauh dan jatuh ke tanah dengan cepat. Orang dapat terinfeksi Covid 19 jika menghirup percikkan orang yang terinfeksi virus ini. Oleh karena itu, penting bagi kita untuk menjaga jarak minimal 1 meter dari orang lain. Percikan-percikan ini dapat menempel di benda dan permukaan lainnya di sekitar orang seperti meja, gagang pintu, 
dan pegangan tangan. Orang dapat terinfeksi dengan menyentuh benda atau permukaan tersebut.

Pandemi virus Corona (Covid 19) masuk ke Indonesia berasal dari warga negara Jepang yang yang berkunjung ke Indonesia yang dinyatakan positif pada bulan Maret tahun 2020 kasus pertama pemerintah membuat kebijakan melakukan tindakan mulai dari mengisolasi rumah pasien, menjaga rumahnya hingga merawat pasien, selanjutnya sejak kasus pertama diumumkan terus berkembang penyebarannya ke daerah-daerah provinsi, kabupaten atau kota. Menurut Masmulyadi, endemi adalah suatu wabah penyakit yang menyebar hingga seluruh dunia. Pandemi Covid 19 yang bersifat global telah berdampak pada seluruh aspek kehidupan. Bermula hanya berdampak pada aspek kesehatan, kemudian meluas ke pada aspek ekonomi, pendidikan, keagamaan, pemerintahan dan pangan. Kebijakan merupakan arah tindakan yang mempunyai maksud yang ditetapkan oleh seorang aktor atau sejumlah aktor dalam mengatasi suatu masalah atau persoalan proses pembuatan kebijakan publik mempunyai tahap-tahap yang dimulai dari tahap penyusun, tahap formulasi kebijakan, tahap adopsi kebijakan, tahap implementasi kebijakan, tahap evaluasi kebijakan dalam mengkaji kebijakan yang dilakukan pemerintah tidak terlepas dari tahap-tahap di atas dengan menggunakan berbagai instrumen dalam menjalankan kegiatan mengatur dan menjelaskan urusan pemerintah dan kemasyarakatan melalui peraturan perundang-undangan, keputusan, peraturan. Pandemi Covid 19 memunculkan sejumlah istilah mengenai kebijakan pembatasan aktifitas atau akses wilayah yang dikenal dengan Lockdown, sejumlah negara menggunakan kebijakan tersebut untuk memutus mata rantai penyebaran virus Corona tersebut. Di Indonesia kebijakan yang diterapkan berupa karantina telah diatur dalam UU No. 6 tahun 2018 tentang kekarantinaan kesehatan didalamnya berisi tentang upaya penanganan melalui pembatasan aktivitas yang terbagi dalam beberapa kebijakan sesuai kebutuhan dan temuan kasus di lapangan pada pasal 49 ayat 1 itu terserah bahwa dalam rangka melakukan tindakan mitigasi faktor risiko di wilayah pada situasi kedaruratan kesehatan masyarakat dilakukan Pertana, karantina rumah merupakan pembatasan penghuni dalam suatu rumah beserta isinya yang diduga terinfeksi penyakit atau terkontaminasi sedemikian rupa untuk mencegah kemungkinan penyebaran penyakit atau kontaminasi. Kedua, karantina wilayah adalah pembatasan penduduk dalam suatu wilayah termasuk wilayah pintu masuk beserta isinya yang diduga terinfeksi penyakit atau terkontaminasi sedemikian rupa untuk mencegah kemungkinan penyebaran penyakit atau kontaminasi. Ketiga, karantina Rumah Sakit merupakan pembatasan seseorang dalam rumah sakit yang diduga terinfeksi penyakit atau terkontaminasi sedemikian rupa untuk mencegah 
kemungkinan penyebaran penyakit atau kontaminasi. Keempat, pembatasan sosial berskala besar oleh pejabat karantina kesehatan.

\section{PENUTUP}

Covid 19 merupakan penyakit menular yang disebabkan corona virus yang baru ditemukan. Ini merupakan virus baru dan penyakit yang sebelumnya tidak dikenal sebelum terjadi wabah di Wuhan, Tiongkok. Corona virus adalah suatu kelompok virus yang dapat menyebabkan penyakit pada hewan maupun manusia. Beberapa jenis corona virus diketahui menyebabkan infeksi saluran nafas pada manusia mulai dari batuk pilek hingga yang lebih serius seperti Middle East Respiratory Syndrome (MERS) dan Severe Acute Respiratory Syndrome (SARS). Pandemi virus Covid 19 di berbagai daerah Indonesia menjadikan pemerintah harus bekerja ekstra dalam upaya memutus mata rantai penyebarannya, dalam situasi ini sejumlah daerah di Indonesia banyak warga yang teridentifikasi positif Corona sehingga daerah tersebut beralih menjadi status siaga bencana, status tanggap darurat, zona merah, zona kuning, dan zona hijau.

Dari persepsi persepsi masyarakat terhadap kebijakan walikota dalam percepatan penanganan Covid 19 berupa adanya perubahan status daerah kota Padangsidimpuan dalam tiga fase yakni status siaga bencana, status tanggap darurat tanpa ada hasil kajian dan penelitian dari BPBD dan dinas Kesehatan Padangsidimpuan dan zona kuning berdasarkan keterangan tertulis ketua gugus penanganan Covid 19 pusat. Dari kajian hasil penelitian ini kiranya dapat membuka cakrawala berpikir dari berbagai kalangan masyarakat terhadap percepatan penanganan Covid 19khususnya di kota Padangsidimpuan yang diperkirakan sampai akhir tahun 2020 masih terjadi ketidak pastian dari wabah Covid 19ini agar jangan sampai virus Corona memecah belah bangsa seperti yang dilakukan Belanda dulu. Ayo bersatu bergotongroyong mengalahkan wabah virus Corona dengan mematuhi peraturan dan himbauan pemerintah.

\section{REFERENSI}

1) Harahap, Yusniar, Nur Halima Akhirani Nasution.2020. Persepsi Masyarakat terhadap Kebijakan Pemerintah Kota Padang Sidempuan dalam Percepatan Penanganan Pandemi Covid 19. Jurnal LPPM UGN. Vol: 10(4). 32-41. 
2) Kartikawati,Erwin dan Betty Gama.2021. Persepsi Masyarakat dan Wartawan di Surakarta tentang Model Pemberitahuan Covid 19. Jurnal ASPIKOM. Vol: 6(1). 167181.

3) Lomboan, Mourine.V, Adisti A. Rumayar, Sam Ratulangi Manado.2020. Gambaran Persepsi Masyarakat Tentang Pencegahan Covid 19 di Kelurahan Talikuran Utara Kecamatan Kawangkoan Utara. Jurnal Kesmas. Vol : 9(4). 111-117.

4) Muhtaruddin dan Budi Dwi Hartanto. 2020. Pengaruh Pandemi Covid 19 terhadap Persepsi Masyarakat Jabodetabek untuk melakukan Perjalanan Mudik. Jurnal Penelitian Transportasi Darat. Vol : 22(2). 107-114.

5) PH,Livana, Laurika,Setiawan,Ike Sariti.2020. Stigma dan Perilaku Masyarakat pada Pasien Positif Covid 19. Jurnal Gawat Darurat. Vol : 2(2). 95-100.

6) Sandi,Jhon Retei Alfi, dkk.2020. Persepsi Masyarakat terhadap Pelaksanaan Pilkada Serentak 2020 saat Pandemi Covid 19 di kabupaten Palangkaraya. Budapest Internasional Research and Critics Institute Journal (BIRCI JOURNAL). Vol : 3(4). 3333-3340.

7) Sari, Devi Pramita, dkk.2020. Hubungan antara Pengetahuan Masyarakat dengan Kepatuhan Penggunaan Masker sebagai upaya Pencegahan Penyakit Covid 19 di Ngronggah. Jurnal Ilmiah Rekan Medis dan Informatika Kesehatan. Vol : 10(1). 52-55

8) Yanti, Ni Putu Emy Darma,dkk.2020. Gambaran Pengetahuan Masyarakat Tentang Covid 19 dan Perilaku Masyarakat di masa Pandemi Covid 19. Jurnal Keperawatan Jiwa. Vol : 8(3). 485-490. 